MARZENNA CICHOSZ

\title{
IT solutions in logistics of smart bike-sharing systems in urban transport
}

Marzenna Cichosz, Ph.D. Warsaw School of Economic (SGH), Department of Logistics

\section{Introduction}

The issue of sustainable urban development in general and sustainable urban transport in particular is the subject of an active interest of the European Union. In the public debate the problem of sustainable urban transport is often reduced to restricting car traffic in the city and reducing the air pollution caused by it. Although the transport is one of the largest polluters, a key aspect underlying the "transport revolution" in the cities is the protection of city cultural environment and the development of sustainable mobility program, including the protection of historic city centers, reinstatement of pedestrian areas, as well as insertion of slow movement areas and bike-sharing programs.

Bike-sharing or public bicycle program is an innovative, environment friendly and social solution for sustainable urban transport. Its application has had profound effect on shaping people's transport behavior, promoting cycling in the city and improving public health, but also increasing the use of bicycle as a mean of transport for point-topoint trips. Public bicycle is also an additional 
service that complements the offer of city transport and provides "the first / the last mile" solution or transit solution that contributes to the comfort and attractiveness of the entire transport system in the city.

Originally the concept of bike-sharing dates back to the 60s. of the twentieth century, but its growth and rapid development wouldn't be possible until improved information technology has allowed better tracking of bikes and supported the management of large number of bikes and rental stations. At the turn of the centuries in Europe, the Americas and Asia the rapid expansion of bike-sharing programs has started. It has been formed in addition to the public transport system mainly in big cities and urban areas (including Amsterdam, Barcelona, Berlin, Brussels, Helsinki, Copenhagen, London, Luxembourg, Lyon, Munich, Paris, Prague, Rome, Seville, Stockholm, Vienna, Washington, DC), but also it has been developed in the towns of the Netherlands, Denmark, Spain, France and Italy.

Public bicycle is a solution that improves not only the city logistics in the field of traffic management, but in itself it is also logistically challenging endeavor. Planning the network, managing large number of bikes and stations in the city system, including the transport of bikes between stations as well as providing logistics solutions for equipment servicing are a few of many challenges.

This study aims at presenting the concept of urban bike-sharing, showing the role of information technology in the development of it and stressing the role of IT solutions in managing the logistics of public bicycles' network. An illustrative case of Warsaw public bicycle "Veturilo" implementation is presented.

The article is based on results of research conducted in 2012 and 2013 by the Department of Logistics at SGH - Warsaw School of Economics. The study focused on "Innovations in urban transport". It consisted of three stages. The first one was desk research analysis of logistics and information solutions related to the reduction of traffic congestion and improvement of sustainable mobility in metropolitan areas of Poland and abroad. The second stage was a survey conducted in 18 provincial cities with representatives of local authorities directly involved in the implementation of projects dedicated to reduce the level of congestion in urban areas. The third stage - interviews were aimed at detailed analysis of selected innovations in management and innovative solutions that reduced the problem of congestion in cities, including analysis of Warsaw public bicycle „Veturilo”. 


\section{Bike-sharing - models of provision}

Bike-sharing or public bicycle programs are based on the principle that one can use a bike when she or he needs it without bearing the costs of its acquisition and maintenance. Bike can be obtained in one location and returned to another. Typically bike is rented for a short period, and all the activities associated with the process of renting and returning user is making by herself or himself. The basic principles of bike-sharing programs are simple, but over the years various models of provision have been developed and implemented. The evolution is divided into three generations of bike-sharing systems (DeMaio 2009, pp. 41-56). The first generation - "white bikes" were introduce in Amsterdam in Holland in 1965. Ordinary bikes, painted white were provided for public use. One could find a bike, ride it to her or his destination and leave it for next user. The main problem of "white bicycles" were vandalism and theft that resulted in shut down of many of such rentals.

The second generation of bike-sharing - „coin-deposit systems" have been introduced in several towns in Denmark in the 90s. of the twentieth century. The advantage of this model over the previous one was primarily based on the introduction of specially designed bikes for intense use that could be picked up and returned only at specific locations in the city center with a coin deposit. While more formalized, this model still had the problem of user anonymity what caused that the bikes were still subject to theft and vandalism.

The third generation bike-sharing schemes, that have enabled public bicycles to become what they are today, are smart bikes - ,information technology-based systems". IT solutions have allowed, on one hand, unique identification of the user with the introduction of city cards, credit cards or mobile phones, on the other hand- RFID tags or GPS transmitters have enabled bicycles tracking. That improved public bicycle safety and protect them better from theft and vandalism. Technology has also contributed to the ability of management of much larger number of bikes and bike-sharing stations, being an important factor in their rapid and global development. The breakthrough moment in public bicycle programs was the year 2005, when French outdoor advertising agency JCDecaux launched "Velo'v" system with 1,500 bicycles in Lyon (France). Two years later JCDecaux started to operate Paris "Velib" program with 7,000 bikes, that has grown to 20,600 bicycles available in Paris today (Henley 2005).

Analyzing the process of launching, management and financing of third generation bicycle-sharing programs it is visible that the operators typically are: advertising agencies, local authorities, public transport operators, for- 
profit companies and non-profit organizations (Shaheen, Guzman, Zhang 2010, pp. 159-167).

The major sources of funding for bicycle-sharing systems are public-private partnerships which accounted for 48 per cent of all systems in 2011. It is the model of cooperation between local government and one of three largest outdoor advertising companies: Cemusa (e.g. in Rome with Bicincitta), Clear Channel (e.g., in New York, Washington) and JCDecaux (e.g. in Vienna, Lyon, Paris). The assumption behind this model is that the advertising agency invests in municipal bike rental system and bears the costs of its operations and management in return for the whole or part of urban advertising space on billboards, street furniture (such as bus stop shelters) and bicycles (Midgley 2011).

Very popular is also a model in which municipal authorities prepare key requirements and financial model of the system, however, launching and management of bike-sharing program is contracted to the third-party operator selected within the framework of competitive tender. Examples of such model is a public bicycle in Barcelona, Burgos, but also Krakow, Poznan, Opole, Warsaw. Another model of provision is a public transport company as the operator of bike-sharing system. This model is popular in Germany and in the Netherlands, where national rail company is the operator, and in Canada e.g. city of Montreal, where city transport company operates the system. They provide bicycles within their infrastructure, such as e.g. railway stations or bus stops. Bike-sharing is an additional service that complements the offer of city transport and provides "the first / the last mile" solution or transit solution that contributes to the comfort and attractiveness of the entire transport system in the city.

An example of for-profit company model is German company Next Bike $\mathrm{GmbH}$. In this model, the role of the city authority is reduced to a minimum. The model is applied in StadtRAD system in Hamburg (Germany).

\section{IT solutions - key component of the third generation's bike-sharing program}

The third generation ",information technology-based systems" are a self-service smart bicycle stations. There are two main categories of self-service stations. The first one - with docking station (special electronically controlled racks) that could be used for locking the bicycle. An example of this model is "Velo'v" in Lyon, "Vélib" in Paris or Warsaw public bicycle „Veturilo". The second one - without dedicated bike-docking station where public bicycles are taken / left at any place within the area covered by the system. To borrow / return a bike one should 
phone the call center. An example of no-docking station model is German „Call a bike", established by Deutsche Bahn in Berlin, Frankfurt and Cologne.

The smart bike stations, both the model with docking stations, as well as no-docking station model, consists of the park of specially designed, highly durable bikes built of customized parts. A second, but very important element of the system is management center that handles the process of renting / returning bikes supported by the integrated information system supervised by the operator / dispatcher. In addition, both models of smart bike stations have logistics back office, i.e. bikes' warehouse (place where bikes are stored during winter), service center (i.e. personnel providing maintenance and repair damage; in large systems, in addition to the permanent service center located mostly within the bikes' warehouse, mobile service centers are introduced, such as floating service center on a barge in Paris) and technical vehicles (used in the case of emergency to bring the technician on site of repair or transport a damaged bike to the service center, or used as a means of transport for bicycle relocation process from one station where is the surplus of bikes to another one where is the shortfall).

The main component that differentiates both models of smart bike systems is the service terminal and bicycle docks. Service terminal / panel within the station allows the user to log in to the system, rent / return bike and make payments. The service panel is also a terminal of public bike card, credit cards and/or travel cards, that could also be an electronic money purse. The service terminal should also allow user for reporting on any damage to the bike. Additional functionality available at terminal is a map of biking routes and bikesharing stations localization in the city. In more advanced systems, the city map is interactive and allows to check current availability of bikes at other stations. Another additional option available at the terminal is weather forecast service. Docking stations are often equipped with bicycle racks that are used for locking bicycles. Modern racks are equipped with electronic locks that at the time of bike's return automatically send information to the management center that the bike is again available for next user.

Depending on the model established by the municipal authorities, there may be fixed or portable stations. Portable modular stations are used during special events (e.g. concerts, matches) and they allow for flexible response to demand's changes. They have their own solar power panels, batteries and wireless network link what simplifies and speeds up the process of their installation in public space. Optionally stations may have a monitoring system but it requires large data files' transfer to the management center and it is used more often when the 
station is connected to fixed power lines and telecommunication public network.

The information system supporting management center is considered as the heart of smart bike system. The following main subsystems are integrated in it (fig. 1):

- rental services management,

- bike repairs and relocation,

- data collection and processing.

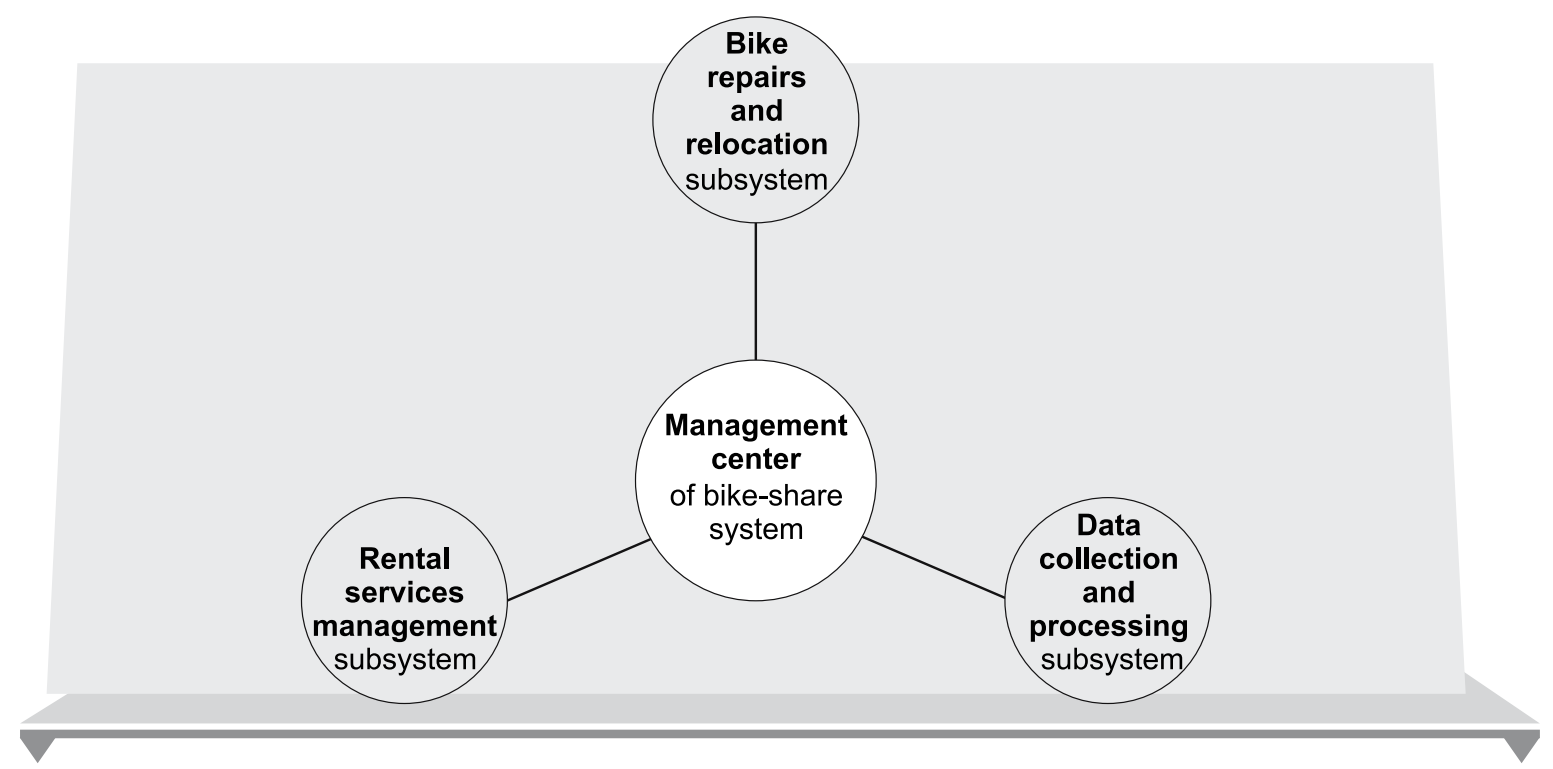

Figure 1. Scheme of information system supporting smart bike-sharing program

Source: own study based on Studium koncepcyjne Systemu Roweru Publicznego dla m.st. Warszawy, Warszawa 2009, p. 91

Each of these subsystems has a number of functionalities, both for users as well as for operator.

From a user's perspective, a prerequisite for the use of self-service bike-sharing program is user's pre-registration. For security reasons most programs require prior registration on the program's website, although in some cities it is allowed to register using the service terminal available at the station. During registration process, user has to complete some information on herself or himself such as: the address, the number of her/his bank account and finally has to pay the initial fee. Later she or he is obliged to pay for using a bike according to applicable tariff. User can pay by money transfer from her/his bank account or directly 
by city card or credit card in service terminal at the station. Additional services available for user at the station are: the information about the bike-sharing scheme, city map with all stations and bike paths. Sometimes it is also possible to check on-line the availability of bikes at each station or take advantage of the service station weather forecast. It is also important for the operator that service terminal at the bike station offers the option to report bike's failure what makes easier to manage the bike and equipment repair.

From the perspective of the operator, the system must support functions such as: user account management (i.e., registration, authorization, blocking the account, verification of user account's balance) calculating charges, editing and displaying any messages to users on both service terminals and websites, tracking bicycles and managing their redistribution, preparing statistics for analysis and forecasts of the demand for bicycles in certain locations at certain times during the day and week.

The system requires communication and exchange of data between the central management system and the individual stations. This is done through fix optical fiber telecommunication lines or wireless communication (e.g. GSM network).

\section{Warsaw public bicycle „Veturilo"}

The beginning of a public bicycle program in Poland dates back to 2008 when the first bike-sharing scheme was established in Krakow. The project was implemented by the Municipality of Krakow under the CARAVEL / CIVITAS II program co-financed by the European Union. For the first three years the system has been operated by "BikeOne” (Polish company, part of Sanmargar Team). At the time of launch "BikeOne” consisted of 12 stations with 100 bicycles. Over the next five years other cities in Poland have established bike-sharing schemes, in particular Rzeszow with 3 stations in 2010, Wroclaw with 7 stations initially in 2011. Significant growth of public bicycle popularity occurred in 2012, due to the launch of bike-sharing programs in Poznan, Opole, Bemowo and mainly in Warsaw. Warsaw public bicycle program "Veturilo" was started on August 1st, 2012, with 1,000 bicycles in 57 locations (Białołęka - 11, Ursynów - 13, Centrum - 31 and in mid-August Wilanów - 2). The consortium of Nextbike Poland Sp. z oo, Nextbike GmbH and Mifa Mitteldeutsche Fahrradwerke AG became the operator of "Veturilo". According to the agreement between consortium and ZTM in Warsaw (Municipal Transport Authority), Nextbike would operate Veturilo until the end of November 2016 and would charge for it total fee of about 19 million PLN. 
Warsaw bike-sharing program was not the first such initiative in Poland, however, it was the biggest one. According to the analyses conducted at the end of 2012 season, key success factor was the scale of investment - so far completely unusual in Poland (68 stations i.e. 57 "Veturilo" stations and 11 "Bemowo Bike” stations from the beginning compatible with "Veturilo"). In 2013 the number of public bicycle station of "Veturilo" has tripled. The network of 58 Veturilo stations has been enlarged by 100 new ones. Cycling zone has grown mostly in the center (about 30 stations), in North and South Praga (about 15 stations) and in: Ochota, Wola, Żoliborz, Mokotów, Targówek, Białołęka and Włochy. Not only Warsaw district authorities, but also private companies including shopping malls: „Arkadia”, „Galeria Mokotów” and business office complex e.g. „Poleczki Business Park", were interested in the project. Until the end of 2013 season 2,500 bicycles had been put in the service in Warsaw (with "Bemowo Bike" 2,600) making "Veturilo" the $8^{\text {th }}$ largest system in Europe.

\section{Logistics challenges and IT solutions supporting „Veturilo's" management}

"Veturilo" is a sustainable public transport solution that has the potential to improve city logistics in the field of passenger transport services. At the same time Warsaw public bicycle is very demanding project from logistics perspective. The challenge is e.g. to plan the network of self-service smart bicycle stations, taking city coverage priorities into account, as well as to manage large number of stations and bicycles, all at the lowest possible cost, offering a level of service that ensures customer satisfaction. IT solutions are coming to help the operator - the consortium Nextbike, but also the manager of "Veturilo" - ZTM in Warsaw while also the user of public bicycles as well. It is the technology and systems that enabled the design and implementation of automated self-service bike stations, often referred to as "smart". While being very easy to use, systems provide a range of additional functionalities for the customer and the operator at the same time enabling a significant reduction in the costs of the service.

More close examination of the logistic challenges associated with the system management of 166 automatic self-service bike rental stations and 2,600 bicycles is the problem of tracking such a numerous park of bicycles. In case of "Veturilo" it is possible thanks to electrolocks installed in racks that are not only doing automatic bicycle locking upon return, but are also sending information to the subsystem managing data on bike rentals, indicating that the bicycle was returned in the given location and can be rented again. The unique identity number of the bicycle is read out from adapters installed on the bike's fork and sent over to the 
management center what allows for precise and fast identification of individual bicycles' location in the system (at the assumption that bike was properly parked and locked).

In order to reduce investment costs, "Veturilo" bicycles weren't equipped with GPS transmitters or RFID tags which would allow for tracking the route and bikes relocation. The IT system managing bike rental doesn't also have a functionality of tracking bicycles. Lack of tracking functionality prevents the remote identification and positioning of the bicycle when improperly parked in the rack and the electrolock didn't close properly. The same problem occurs if the user incorrectly declared the place of leaving of bicycle (the user is submitting such declarations through SMS or over the phone if at the moment of return the user is locking the bicycle with security lock into other bicycle, due to unavailability of free rack slots).

Precise information on the number of bicycles available in individual locations allows to identify those stations with surplus and those with deficiency of bicycles. Such information is the base for decision making process for bicycle relocation. Relocation is performed by the dedicated relocation section, equipped with special vehicles being used for a transport of large number of bicycles simultaneously. These are usually vehicles with trailer or vehicles with large loading container. The relocation section is using information from repairs and relocation IT subsystem.

An identification of equipment's defects and an organization of their repairs are the next logistic challenge associated with the public bicycles rentals. For that purpose information from two different sources is being used: mobile service and repair team that visits stations daily, and directly from users. Users can provide information about defect of equipment using panel input screen at the station or report it over the phone or e-mail to the customer service department. Information about defects are recorded in repairs and relocation IT subsystem so that several service teams can more effectively plan their work, optimizing routes, field visits or transporting the damaged equipment to the main repair center located next to bicycles central warehouse in Warsaw-Młociny district. Possibility of tracking bicycles, identification of defects, as well as effective organization of bicycles relocation and organization of repairs allow the operator to maximize bicycles fleet usage. Data collection and processing subsystem provides the operator with key information necessary to analyse rental statistics at each station, including details on hourly, daily and weekly demand, so that effectiveness of each station can be assessed and further optimization of station network performed. 
Moving and relocation of the station itself is easily possible thanks to its portable modular construction anchored in the given place. Every station is equipped with its own solar panels, battery and connected to management center via cellular network. Consequently, bicycles together with the station can be relocated to another location where demand is higher and bicycles are rented more frequently, thus contributing to overall system efficiency.

\section{Future of public bicycles}

The number of smart bike-sharing programs is growing in cities around the world as well as in Poland with such cities like Torun, Gdańsk and Sopot preparing to implement it. Urban smart bike-sharing concept is still being improved and enriched by further technical innovations that offer new functionalities for both customers and operators. There are on-going research on solutions that facilitate the installation of bicycle rental stations in urban area, improve the performance of power stations, reduce the cost of tracking the bike. Those future solutions, when installed in public bikes, will offer to users such functions like ability to create individual cycling profile and share it within the social network of other cyclists. An important challenge is to improve the efficiency of bicycles' redistribution, especially during rush hours. Operators work on introduction of advanced programs supported by IT solutions that promote certain users behavior to relocate or return the bike to those stations, where there is usually a deficit of bikes, offering the user in exchange additional free minutes of public bike ride.

\section{Summary}

\section{IT solutions in logistics of smart bike-sharing systems in urban transport}

In recent years, the public transport of Krakow, Rzeszow, Wroclaw, Poznan, Opole and Warsaw has expanded into the third generation bike-sharing programs - smart bikes. It's an innovative solution, deploying IT systems and technology to integrate individual stations of urban bike rental system. The article presents the business model solution, its functionality from the perspective of customers and operator, and shows the role of IT solutions support in managing the logistics of rental network. An illustrative case of "Veturilo" solution implementation is presented. 
Key words: Bike-sharing, public bike, urban logistics, sustainable urban transport.

\section{Streszczenie}

\section{Rozwiązania informatyczne wspierające logistykę wypożyczalni rowerów publicznych $\mathrm{w}$ miastach}

Na przestrzeni ostatnich lat krakowski, rzeszowski, wrocławski, poznański, opolski i warszawski system transportu publicznego wzbogacił się o automatyczne samoobsługowe wypożyczalnie rowerów miejskich trzeciej generacji (smart bikes). Jest to innowacyjne rozwiązanie, wykorzystujące systemy i technologie informatyczne, umożliwiające integrację pojedynczych stacji $\mathrm{w}$ system wypożyczalni rowerów miejskich. W artykule przedstawiono model działania rozwiązania, jego funkcjonalność z perspektywy klienta i operatora oraz pokazano rolę wsparcia informatycznego w zarządzaniu logistyką sieci wypożyczalni. Jako ilustracje omawianych zagadnień zaprezentowano przypadek wdrożenia Veturilo.

\section{Słowa}

kluczowe: Rower publiczny, logistyka miejska, zrównoważony rozwój transportu miejskiego.

\section{References}

1. Bike sharing world map: http://bike-sharing.blogspot.com/2013/04/ the-bike-sharing-world-mid-april-2013.html.

2. DeMaio P. (2009), Bike-sharing: History, Impacts, Models of Provision, and Future, „Public Journal of Transportation” Vo. 12, No. 4.

3. Henley J. (2005), Rentabike moves up a gear from curiosity to runaway success, "The Guardian" August 12 ${ }^{\text {th }}$.

4. Midgley P. (2011), Bicycle-sharing schemes: Enhancing sustainable mobility in urban areas, United Nations Department of Economic and Social Affair, Commission on Sustainable Development, N.Y.

5. Myszkowski M. (2008), Rower publiczny dla Warszawy, Urząd Miasta Stołecznego Warszawy, Biuro Drogownictwa i Komunikacji, Warszawa.

6. Shaheen S.A., Guzman S., Zhang H. (2010), Bikesharing in Europe, the Americas, and Asia. Past, Present, and Future, "Jounal of the Transportation Research Board" No. 2143.

7. Studium koncepcyjne systemu roweru publicznego dla M. St. Warszawy, Urząd Miasta St. Warszawy Biuro Drogownictwa i Komunikacji (2009), Warszawa, grudzień. 
8. Interview conducted on May 13, 2013, with Mrs. Maria Przytulską Head of the Program Analysis Division in the Office of Transportation and Road Infrastructure, Authority of the Capital City of Warsaw and on May 14, 2013 with Mr. Łukasz Puchalski - Head of the Department of Communication Hubs' Management in Warsaw ZTM (Municipal Transport Authority) and Mr. Marcin Czajkowski - inspector of the Department of Communication Hubs' Management in Warsaw ZTM (Municipal Transport Authority). 